\title{
Hexose transport in preimplantation rabbit blastocysts
}

\author{
D. H. Robinson $\ddagger$, P. R. Smith*† and D. J. Benos \\ Department of Physiology and Biophysics, University of Alabama at Birmingham, Birmingham, \\ AL 35294, USA; and *Department of Anatomy and Cell Biology, Medical University of South \\ Carolina, Charleston, SC 29425, USA
}

\begin{abstract}
Summary. Transtrophectodermal 3-0-methyl glucuse (3-0MG) transport in the rabbit blastocyst at Days 6 and 7 post coitum was investigated to understand better how the trophectoderm can regulate inner cell mass growth by controlling substrate availability. 3-0MG rapidly traversed the trophectoderm and displayed saturation kinetics $\left(K_{\mathrm{m}}=4.3 \pm 0.5 \mathrm{mM}, \mathrm{V}_{\max }=79 \pm 3.8 \mathrm{nmol} \cdot \mathrm{cm}^{-2}\right)$. The flux of 3-0MG was inhibited nearly $95 \%$ by $10^{-4} \mathrm{M}$-phloretin, and only $15 \%$ by $10^{-4} \mathrm{M}$-phlorizin. Furthermore, $3-$ $0 \mathrm{MG}$ influx was inhibited by cytochalasin $\mathrm{B}(5 \mu \mathrm{M})$ and was unaffected by removal of sodium. The transport system had a high specificity for 2-deoxy-D-glucose and glucose, and a very low specificity for fructose and 4- $\alpha$-methyl glucoside. Western blots probed with a polyclonal antibody to the human erythrocyte glucose transport protein and also with a polyclonal antibody to the C-terminus of the glucose transport protein of the rat brain revealed a broad band with a molecular weight of 55000 . Using immunogold labelling techniques, $\mathrm{Na}^{+}$-independent glucose transporters were localized to both the apical and basolateral borders of the trophectodermal cell. These results suggest that the mechanism in the trophectoderm responsible for transport of glucose is similar to other sodium-independent glucose transport systems. In addition, 3-0MG influx was unaffected by short-term incubation with progesterone, the progesterone antagonist mifepristone (RU-486), PGF-2 $\alpha$, PGE-2, insulin, or cAMP. Day-7 p.c. embryos also transported hexoses by a similar system because the influx rate and the phlorizin/ phloretin sensitivity were the same as in the Day-6 p.c. embryo.
\end{abstract}

Keywords: preimplantation embryo; 3-0-methyl glucose; sugar transport; rabbit

\section{Introduction}

The trophectoderm of the preimplantation rabbit blastocyst forms a continuous barrier that separates the outer uterine fluid from the fluid contained within the blastocoele (Hastings \& Enders, 1975). As a result, the trophectodermal cells control the environment that bathes the developing embryo. The trophectoderm can therefore be considered to have a role in modulating the growth of the embryo through the regulation of the $\mathrm{pH}$, amino acid content, and the concentrations of other metabolic substrates within the blastocoele.

These solutes most probably traverse the trophectodermal cell by a system of protein channels, carrier molecules, and/or ATP-driven ion pumps. The flux rate of organic molecules via paracellular pathways has been found to be low (Robinson et al., 1989), and this is undoubtedly a consequence of the tight junctions formed between trophectodermal cells (Hasting \& Enders, 1975; Benos, 1981). Therefore, regulation of transcellular solute transport systems (i.e. specificity, number, or de-novo synthesis of transporter proteins), can be causally related to growth regulation

†Present address: Department of Physiology and Biophysics, University of Alabama at Birmingham, Birmingham, AL 35294, USA.

¥Present address: Worcester Foundation for Experimental Biology, 222 Maple Ave., Shrewsbury, MA 01545, USA. 
of the embryonic inner cell mass (ICM). For the ICM to have access to glucose, which is utilized by the embryo as an energy source (Fridhandler, 1961), hexose carriers must then exist in the trophectodermal cells.

In general, glucose can cross the plasma membrane of cells by at least two distinct mechanisms. The first is a sodium-coupled glucose transporter which is found in the apical border of absorptive epithelia (e.g. digestive tract and proximal tubule of the nephron; reviewed by Ullrich, 1979; Esposito, 1984). Glucose transport by this system is inhibited by phlorizin, and, indirectly, by ouabain. In addition, the glucose analogue 4- $\alpha$ methyl glucoside has a high affinity for this system. The second glucose transport system involves a carrier mechanism which operates independently of sodium (Kinne et al., 1975; Gliemann \& Rees, 1983). This transport system has been extensively studied in adipose tissue, brain and the human erythrocyte, and is also located on the basolateral membrane of the enterocyte and the proximal tubule cell (Kinne et al., 1975; Esposito, 1984). This transport system is pharmacologically distinct from the sodium coupled system in that cytochalasin $\mathrm{B}$ and phloretin are potent, specific inhibitors, while phlorizin is without effect. In addition, the hexose analogue 2-deoxy-D-glucose has a high affinity for this system.

There are a few studies which address the issue of glucose transport in mammalian embryos (Perinchief, 1980; Dabich \& Acey, 1982; Gardner \& Leese, 1988). However, none of these studies addresses the phenomenon of transtrophectodermal transport. We used transtrophectodermal 3-0-methyl glucose flux studies and also polyclonal antibodies raised against either the human erythrocyte glucose transport protein or an artificial peptide homologous to the rat brain glucose transporter C-terminus to characterize and localize the glucose transport system in the rabbit embryo.

\section{Materials and Methods}

Collection of blastocysts. New Zealand White rabbits, 69 months of age, were mated to fertile bucks. At various times after mating, the females were killed by intravenous injection of $1.5 \mathrm{ml} \mathrm{T}-61$ euthanasia solution (American Hoechst Corp., Somerville, NJ, USA). For embryos at 6 days post coitum ( p.c.; Day $1=$ day of mating), the uterine horns were exposed and the blastocysts were flushed from the uteri with Krebs'-Ringer-bicarbonate with glucose (KRBG) consisting of (in mM): $\mathrm{NaCl}, 1$ I $9 ; \mathrm{NaHCO}_{3}, 25 ; \mathrm{KCl}, 4 \cdot 7 ; \mathrm{KH}_{2} \mathrm{PO}_{4}, 1 \cdot 2 ; \mathrm{MgSO}_{4}, 1 \cdot 2 ; \mathrm{CaCl}_{2}, 1 \cdot 7 ; \mathrm{D}$-glucose, 5.5; and $\mathrm{N}$-2-hydroxyethylpiperizine- $\mathrm{N}^{\prime}$-2-ethanesulphonic acid (Hepes), 20; $\mathrm{pH}$ adjusted to 7.4. The Day-7 p.c. embryos were collected by excising the uteri and gently dissecting the blastocysts out into a Petri dish containing cold KRBG. The blastocysts were then placed in cold $\left(4^{\circ} \mathrm{C}\right) \mathrm{KRBG}$ until the start of the experiment. Previous studies have indicated that pre-incubation in the cold has no effect on ion or solute transport activity (Robinson et al., 1989).

Influx measurements. $\left[{ }^{14} \mathrm{C}\right] 3-0$-methyl glucose (New England Nuclear, Boston, MA, USA; $304 \cdot 7 \mathrm{mCi} / \mathrm{mmol}$ ), was diluted to $50 \mu \mathrm{Ci} / \mathrm{ml}$ in distilled water after first allowing the ethanol/water in which the isotope was packaged to evaporate under an $\mathrm{N}_{2}$ stream. Trace amounts $(0.5-1 \mu \mathrm{Ci} / \mathrm{ml})$ were added to $0.5 \mathrm{ml} \mathrm{Krebs'-Ringer-bicarbonate} \mathrm{with-}$ out glucose, containing in addition $1 \mathrm{~mm}$ unlabelled 3-0MG. After incubation of the blastocyst for an appropriate time, the embryo was removed and washed three times in cold KRB + I mM-3-0MG; the long and short axes were measured, and the blastocoele fluid was collected by micropuncture (pipette tip diameters of $5 \mu \mathrm{m}$ ). Measurement of blastocyst dimensions and fluid collection (described in Robinson et al., 1989) were completed within 3 min of the first wash. Significant loss of tracer from the blastocoele during this wash procedure has not been noted in this study or in a previous study (Robinson et al., 1989). The collected fluid was placed under oil for later analysis. A single volume of the collected blastocoele fluid (up to $10 \mu \mathrm{l}$ for the Day-6 p.c. embryos and $50 \mu \mathrm{l}$ for Day- 7 p.c. embryos) was measured with a lambda pipette and transferred to a scintillation vial. Then two 10- $\mu 1$ samples of bathing fluid were collected and placed in scintillation vials for counting, $4 \mathrm{ml}$ Aqueous Counting Scintillant (Amersham Corp., Arlington Heights, IL, USA) were added to each vial, and the samples were counted in a Packard scintillation counter, Model $2000 \mathrm{CA}$.

Immunoelectron microscopy. Day- 6 p.c. blastocysts were fixed in freshly prepared $2 \%$ formaldehyde plus $0 \cdot 1 \%$ glutaraldehyde in $0.1 \mathrm{M}$-phosphate buffer $\left(\mathrm{pH} \mathrm{7.4)}\right.$ at $4^{\circ} \mathrm{C}$ for $45 \mathrm{~min}$. After fixation, tissues were washed for $1 \mathrm{~h}$ in $0.1 \mathrm{M}-\mathrm{NH}_{4} \mathrm{Cl}$ in buffer, dehydrated in a graded series of ethanols $(50 \%, 1 \mathrm{~h} ; 75 \%, 1 \mathrm{~h} \times 2)$ and infiltrated overnight in L.R. White resin (Polysciences, Inc., Warrington, PA, USA) in BEEM capsules (all at $4^{\circ} \mathrm{C}$ ). Tissues were subsequently polymerized in fresh L.R. White resin at $60^{\circ} \mathrm{C}$ for $24 \mathrm{~h}$. Thin sections were cut with a diamond knife on a Reichert Ultracut 3 ultramicrotome and collected on bare hexagonal 300-mesh nickel grids.

Immunolabelling was performed at room temperature and the buffer (TBS-BSA) used in all stages consisted of $20 \mathrm{~mm}$-Tris, $\mathrm{pH} 7.4,0.5 \mathrm{M}-\mathrm{NaCl}$ and $0.1 \%$ bovine serum albumin (BSA). Grids were sequentially floated section side

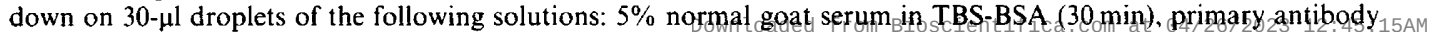


(affinity-purified rabbit anti-human erythrocyte glucose transporter, courtesy of $\mathrm{Dr}$ G. Lienhard, Dartmouth Medical School, Hanover, NH, USA) diluted $1: 40$ in TBS-BSA containing $1 \%$ normal goat serum $(1.5 \mathrm{~h})$, TBS-BSA $(5 \times 2 \mathrm{~min}$ ), secondary antibody (goat anti-rabbit IgG conjugated to $10 \mathrm{~nm}$ colloidal gold particles; Janssen Life Sciences, Piscataway, NJ, USA) diluted $1: 3$ in TBS-BSA containing $1 \%$ normal goat serum $(1.5 \mathrm{~h})$, TBS-BSA $(5 \times 2 \mathrm{~min})$, and phosphate-buffered saline (PBS, pH 7.4) $(2 \times 2 \mathrm{~min})$. Labelled sections were subsequently fixed in $2 \%$ glutaraldehyde in PBS $(5 \mathrm{~min})$ and washed in distilled water $(3 \times 2 \mathrm{~min})$. Sections were examined unstained in a JEOL $100 \mathrm{CX}$ transmission electron microscope operating at $60 \mathrm{kV}$.

Gel electrophoresis and Western blotting. Sodium dodecylsulphate-polyacrylamide gel electrophoresis (SDSPAGE) was carried out in a Bio-Rad (Richmond, CA, USA) Mini Protean Il slab gel apparatus using the discontinuous buffer system of Laemmli (1970). Rabbit embryos (6 or 7 days p.c.; $n=5-8$ ) were solubilized in sample buffer containing $2.5 \%$ SDS, $13 \mathrm{~mm}$-dithiothreitol, and $50 \mathrm{~mm}$-Tris- $\mathrm{HCl}$ (pH 6.8) with $1 \mathrm{~mm}$-phenylmethylsulphonic acid and $1 \mu \mathrm{g} /$ leupeptin/ml. The embryos were sheared by drawing the sample into a 27 -gauge needle. The samples were then run on an $8 \%$ gel. In this preparation, there was some difficulty with the glucose transport protein running on the gel in polymeric form. This tendency of the protein to form polymers was decreased by not boiling the sample before loading on the gel. However, some high molecular weight complexes were still apparent (see Figs $6 \mathrm{a}, \mathrm{b}$ ). Electrophoresis was performed at a constant voltage of $100 \mathrm{mV} / \mathrm{gel}$.

Western blot analysis was performed by electrophoretically transferring the protein in the gel to nitrocellulose using a Bio-Rad Mini Trans-Blot Cell (25 mm-Tris, $20 \% \mathrm{v} / \mathrm{v}$ methanol, $192 \mathrm{~mm}$-glycine, pH 8.3 transfer buffer; $100 \mathrm{~V}$ constant current for $1 \mathrm{~h}$ ). Non-specific protein binding sites on the nitrocellulose were blocked by a 1-h exposure to $2 \%$ dry non-fat milk in Tris-buffered saline (Tris, $20 \mathrm{~mm} ; \mathrm{NaCl}, 500 \mathrm{~mm}$ ) with $0.05 \%$ Tween-20 (TTBS). The nitrocellulose-bound protein was subsequently overlayed with $0.8 \mu \mathrm{g} / \mathrm{ml}$ of the rabbit anti-human erythrocyte glucose transporter or with serum (diluted 1:2500) from a rabbit immunized with an artificial peptide corresponding to the C-terminus of the rat brain glucose transport protein (East Acres Biologicals, Southbridge, MA, USA) (both in TTBS $+1 \%$ non-fat milk). Following incubation at room temperature for $2 \mathrm{~h}$, the blots were washed with two TTBS rinses ( $5 \mathrm{~min}$ each), then goat anti-rabbit IgG alkaline phosphatase (Boehringer Mannheim Biochemical, Indianapolis, IN, USA) diluted 1:5000 in TGBS + 1\% non-fat milk was added for $1 \mathrm{~h}$. After 2 washes in TTBS, colour development was accomplished with the BCIP/NBT colour development assay kit (Bio-Rad). USA.

Chemicals. Unless otherwise stated, chemicals were obtained from Sigma Chemical Company, St Louis, MO,

Statistics. Comparisons between means were performed with an unpaired $t$ test or analysis of variance and the Student-Newman-Keuls test. Data are expressed as mean \pm standard error.

\section{Results}

\section{Kinetics of 3-0MG transport}

The time course of $1 \mathrm{~mm} 3-0 \mathrm{MG}$ uptake was investigated to determine the rate at which this hexose analogue traverses the trophectoderm. Movement of 3-0MG across the trophectoderm was rapid, and the half-time of the uptake was $35.7 \pm 1.9 \mathrm{~min}$ (Fig. 1). The maximum uptake, as determined from a non-linear curve-fitting program was $63.5 \pm 1.7 \mathrm{nmol} \cdot \mathrm{cm}^{-2}$. Because the velocity of the uptake was linear within the first $10 \mathrm{~min}$, this time point $(10 \mathrm{~min})$ was used in all subsequent experiments.

If 3-0MG is transported via a saturable mechanism across the trophectoderm, the uptake of the hexose should display a concentration dependence that is characteristic of Michaelis-Menten kinetics. Results indicate (Fig. 2) that the uptake displays kinetic characteristics that can be described by the Michaelis-Menten equation. The concentration for half-maximum uptake $\left(K_{\mathrm{m}}\right)$, as determined by a non-linear curve fitting programme with a diffusion factor included to account for paracellular movement of $3-0 \mathrm{MG}$, was $4.3 \pm 0.5 \mathrm{mM}$, and the calculated $V_{\max }$ was $79 \pm 3.8 \mathrm{nmol} \cdot \mathrm{cm}^{-2} / 10 \mathrm{~min}$.

\section{Transport inhibitors}

The dose-response relationships of phlorizin, an inhibitor of $\mathrm{Na}^{+}$-dependent hexose transport, and of phloretin, which inhibits $\mathrm{Na}^{+}$-independent hexose transport (Esposito, 1984), were examined for Day-6 p.c. embryos (Fig. 3). Transport of 3-0MG was inhibited to a much greater extent by phloretin $\left(K_{\mathrm{i}}=6 \mu \mathrm{M}\right)$ than by phlorizin. At $10^{-4} \mathrm{M}$ the inhibition 0 [3-0MG transport by/phloretin: $45: 15 \mathrm{AM}$ 


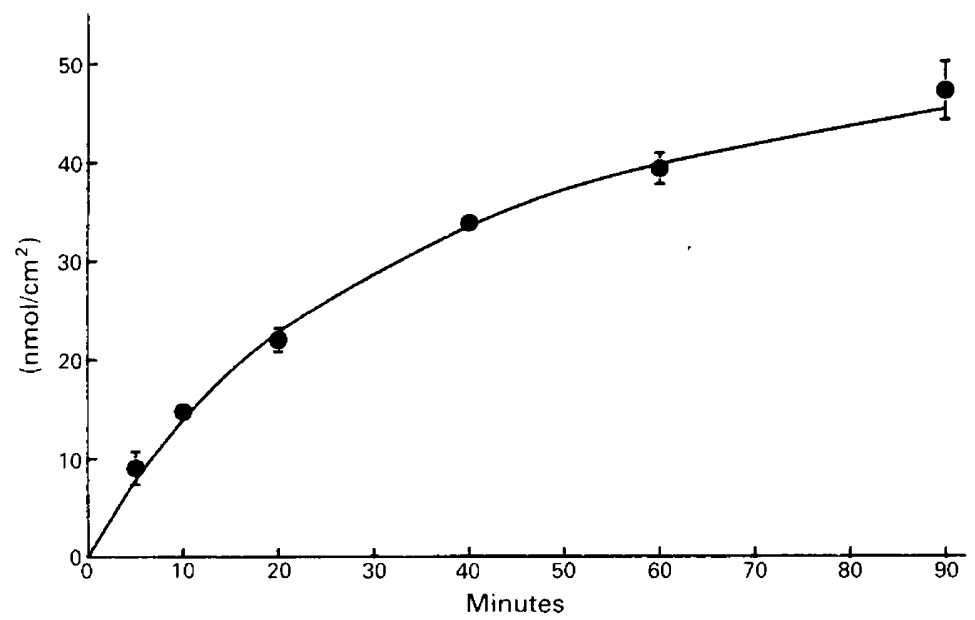

Fig. 1. Plot depicting the tíme-dependence of $1 \mathrm{~mm}-3-0-$-methyl glucose uptake in Day-6 p.c. rabbit embryos. The error bars are within some symbols $(n=3-4$ for each point).

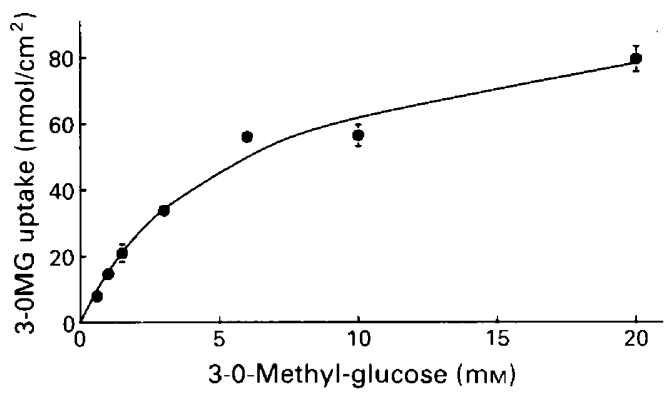

Fig. 2. Plot depicting the concentration-dependence of uptake of 3-0-methyl glucose during a 10 -min time period. The error bars are within some symbols $(n=3-4$ for each point $)$.

was nearly complete $(94 \pm 2 \%)$ whereas phlorizin at this concentration inhibited 3-0MG transport by only $15 \pm 8 \%(P<0.0005)$.

Next, $5 \mu \mathrm{M}$-cytochalasin $\mathrm{B}$, which is an inhibitor of the $\mathrm{Na}^{+}$-independent hexose transport system $\left(K_{\mathrm{i}}=0 \cdot 1-0 \cdot 15 \mu \mathrm{M}\right.$; Gliemann \& Rees, 1983; Lavis et al., 1987), was examined for its effect on uptake of $1 \mathrm{mM}-3-0 \mathrm{MG}$ at 5 and $10 \mathrm{~min}$. The influx (as calculated from the slope of the time-dependent uptake curve) was decreased by this agent from a control value of $1 \cdot 14 \pm 0.36 \mathrm{nmol} \cdot \mathrm{cm}^{-2} \cdot \mathrm{min}^{-1}, n=8$, to a value of $0.24 \pm 0.07 \mathrm{nmol} \cdot \mathrm{cm}^{-2} \cdot \mathrm{min}^{-1}, n=7(P<0.025)$.

\section{Transport specificity}

We next examined the effect of glucose, fructose, and glucose analogues on the transtrophectodermal transport of $1 \mathrm{mM}-3-0 \mathrm{MG}$ as a means of further defining the characteristics of the hexose transporter present in the apical membrane of the blastocyst. Results of these experiments (Fig. 4) indicate that the compound 2-deoxy-D-glucose, which is specific for the $\mathrm{Na}^{+}$-independent transport mechanism (Esposito, 1984), was at least as efficacious as glucose in inhibiting 3-0MG transport. 4- $\alpha$-Methyl-glucoside, which has a high affinity for the $\mathrm{Na}^{+}$-dependent system, was only slightly more effective than fructose at inhibiting the 3-0MG flux. 3-0MG was intermediate in its effectiveness. 


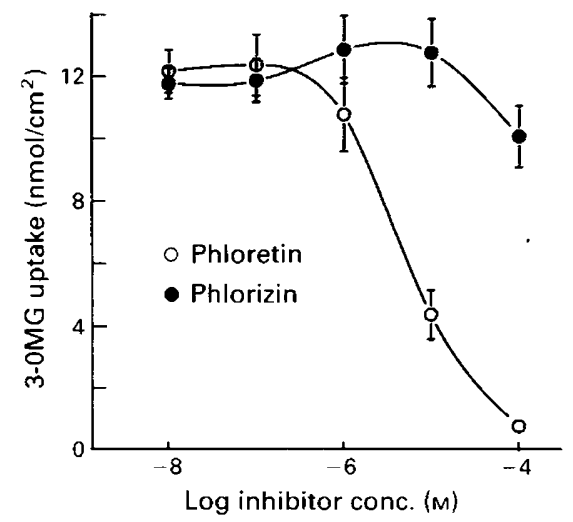

Fig. 3. Plot depicting the inhibition of the 10-min 3-0-methyl glucose uptake by phloretin and phlorizin in Day-6 p.c. rabbit embryos. The error bars are within some symbols $(n=3$ for each point).

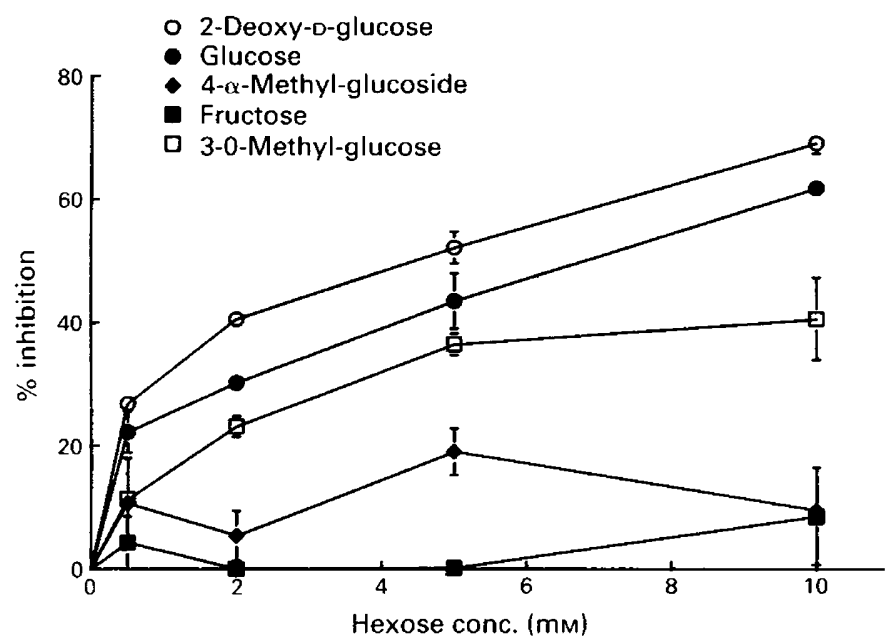

Fig. 4. Graph depicting the efficacy of hexoses and hexose analogues at inhibiting 3-0-methyl glucose uptake in Day-6 p.c. rabbit embryos. The error bars are within some symbols $(n=3$ for each point).

\section{Sodium dependence}

Uptake was then assessed in $\mathrm{KRB}$ in which the $\mathrm{NaCl}$ was replaced with $\mathrm{N}$-methyl-D-glucamine$\mathrm{Cl}$, and the $\mathrm{NaHCO}_{3}$ was replaced with choline bicarbonate, thus making the incubation solution $\mathrm{Na}^{+}$-free. The control 10 min uptake value of $13.0 \pm 0.6 \mathrm{nmol} \cdot \mathrm{cm}^{-2}(n=5)$ was not different from that measured in $\mathrm{Na}^{+}$-free solutions, namely $12.7 \pm 0.6 \mathrm{nmol} \cdot \mathrm{cm}^{-2}(n=5)$.

\section{Hormone effects}

Sodium-independent glucose transport proteins can be increased in the plasma membrane by the hormone insulin (Kahn \& Cushman, 1986) within $10 \mathrm{~min}$. In addition, the mouse embryo is able to bind insulin at the blastocyst stage (Rosenblum et al., 1986). We investigated whether glucose transport by the rabbit embryo can be increased by maximal $\left(10^{-7} \mathrm{M}\right)$ concentrations of

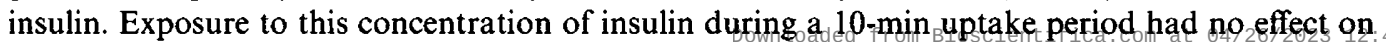


the flux of 3-0MG (control, $10.6 \pm 0.8 \mathrm{nmol} \cdot \mathrm{cm}^{-2}$; insulin, $10.0 \pm 0.5 \mathrm{nmol} \cdot \mathrm{cm}^{-2} ; N=5$ ), for both treatments).

We tested the effect of progesterone at a physiological level $(15 \mathrm{ng} / \mathrm{ml}$; Nielsen et al., 1987) on the uptake of 3-0MG to determine whether this pregnancy-associated hormone had any effect on hexose uptake. The experimental protocol embodied the following three conditions: (1) control, 1-h preincubation in KRBG; (2) 1-h preincubation in progesterone, followed by measuring the uptake of 3-0MG in the presence of progesterone; and (3) the same pre-treatment as (2) but with the uptake performed in the absence of progesterone. The results indicate that progesterone at this physiological concentration had no effect on hexose transport (treatment $1,11.5 \pm 1 \cdot 1 \mathrm{nmol} \cdot \mathrm{cm}^{-2}$; treatment $2,10 \cdot 6 \pm 0.4 \mathrm{nmol} \cdot \mathrm{cm}^{-2}$; treatment $3,10 \cdot 1 \pm 0.6 \mathrm{nmol} \cdot \mathrm{cm}^{-2} ; n=5$ for each). A $1-\mathrm{h}$ preincubation with $10^{-7} \mathrm{M}$-mifepristone (a progesterone antagonist) also did not alter the rate of hexose transport in the embryo (control, $8.30 \pm 0.49 \mathrm{nmol} \cdot \mathrm{cm}^{-2} ;$ mifepristone, $9.03 \pm 0.28 \mathrm{nmol} \cdot \mathrm{cm}^{-2}, n=6$, for both), indicating that progesterone, at least on a short-term basis, had no effect on the glucose transport system.

The prostaglandins (PG) E-2 and F-2 $\alpha$ are reported to have an effect on the metabolism of glucose in embryos of other species (Khurana \& Wales, 1987b). If these hormones also have metabolic effects in the rabbit embryo, it is possible that these metabolic changes would be accompanied by changes in the rate of hexose transport. Our results demonstrate that there was no effect of PGF$2 \alpha\left(4 \times 10^{-6} \mathrm{M}\right.$; control, $10 \cdot 9 \pm 0 \cdot 4, n=4 ;$ PGF- $\left.2 \alpha, 10 \cdot 7 \pm 0 \cdot 8, n=4\right)$, or PGE-2 $\left(10^{-6} \mathrm{M}\right.$; control $13 \cdot 7 \pm 0 \cdot 5, \mathrm{n}=3$, PGE-2, $12 \cdot 8 \pm 1 \cdot 2, n=3$ ), on hexose flux in Day- 6 p.c. embryos.

Some glucose transport systems are affected by cAMP (Joost et al., 1986). To test whether cAMP has any effect on hexose flux in the rabbit embryo, we examined the change in transtrophectodermal transport of 3-0MG in the presence of two concentrations $\left(10^{-5} \mathrm{M}\right.$, and $\left.10^{-4} \mathrm{M}\right)$ of forskolin, a compound which is known to elevate intracellular levels of cAMP. Forskolin clearly caused a decrease in 3-0MG flux in a dose dependent manner (Fig. 5). However, a similar result was obtained with $10^{-4} \mathrm{M}$ dideoxyforskolin, an analogue which does not activate adenylate cyclase. Additionally, chlorophenylthio (CPT) cAMP $\left(10^{-4} \mathrm{M}\right)$ has no effect (Fig. 5). These results indicate that the hexose transport in the rabbit embryo is not modulated by cAMP.

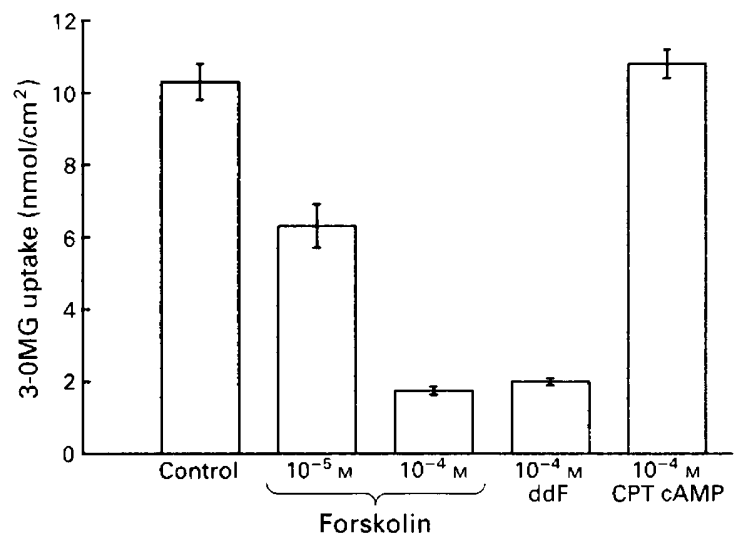

Fig. 5. Effect of forskolin, dideoxyforskolin (ddF), and chlorophenylthio (CPT) cAMP on the 10-min 3-0-methyl glucose uptake in Day-6 p.c. rabbit embryos ( $n=4-9$ for each point).

\section{Localization studies}

The anti-erythrocyte glucose transporter antibody used in this study was first tested for reactivity in the rabbit embryo by Western blot analysis wewestern blotting demonstrates \& Fig. 6a) major $_{15 \mathrm{AM}}$ 
bands at molecular masses of 55000 and 110000 . The band of $M_{\mathrm{r}} 55000$ coincides with the molecular mass of known glucose transporters (Matthaei et al., 1987; Blok et al., 1988; Lucas \& Zigler, 1988). The band at $M_{\mathrm{r}} 110000$ is a dimer of the glucose transport protein. Dimerization of the protein has been observed in other experiments (Lienhard et al., 1984). Under our conditions, we have observed nearly complete dimerization of the protein when the sample is heated before loading on the gel. Although these samples (Fig. 6) were not heated, we suggest that the heat generated in the mini-gel causes dimerization to occur. Because there is a slight possibility that this glucose transport antibody could be reacting with cytoskeletal proteins, we also examined Western blots probed with an antibody generated against the $C$-terminus portion of the glucose transporter peptide. This blot (Fig. 6b) is identical to Fig. 6(a), indicating specificity of the antibody raised against the erythrocyte glucose transport protein.

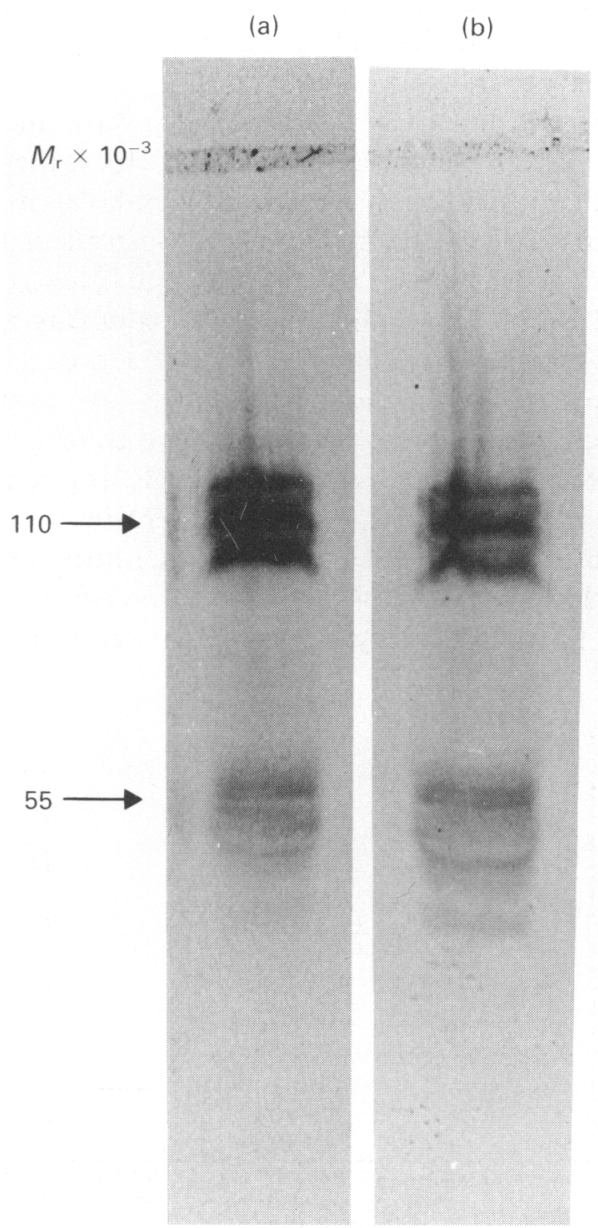

Fig. 6. Western blot of solubilized 6 day p.c. embryos probed with (a) the anti-erythrocyte glucose transport protein antibody, performed as described in the text and (b) the anti-rat brain glucose transporter C-terminus antibody. Molecular weights of the bands were determined from the position of molecular weight markers. Western blots for Day-7 p.c. were similar in appearance.

Immunogold labelling with the rabbit anti-human erythrocyte glucose transporter antibody reveals colloidal gold particles at both the apical and basolateral borders of the trophectodermal cell (Figs $7 \mathrm{a}, \mathrm{b})$. This indicates that a similar transport protein $_{\mathrm{i}} \mathrm{s}_{\mathrm{B}}$ localized $_{\mathrm{i}}$ to both sides $/ \mathrm{of}_{2}$ the 

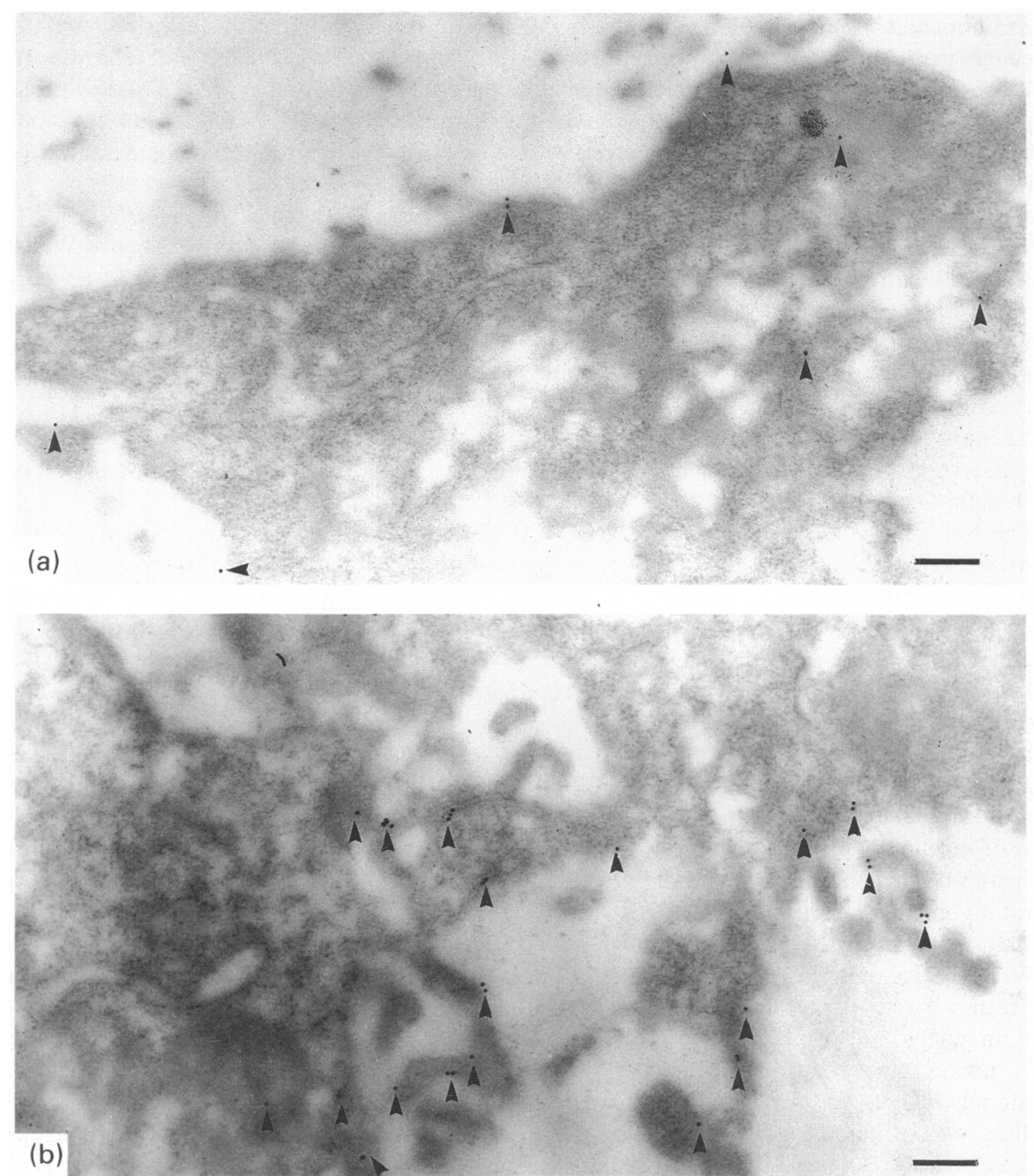

Fig. 7. Immunogold labelling of glucose transport proteins (arrows) in Day-6 p.c. trophectodermal cells: (a) Apical membrane of a trophectodermal cell; (b) Basolateral membrane of a trophectodermal cell. Bar $=0 \cdot 25 \mu \mathrm{m}$.

trophectodermal cell. The basolateral membrane, when qualitatively compared with the apical membrane of the same cell, consistently had a greater colloidal gold particle density.

\section{Transport in 7-day p.c. blastocyst}

Other transport systems in the trophectoderm of the rabbit blastocyst are known to change as a function of developmental age (reviewed by Biggers et al., 1988). Phloretin and phlorizin $\left(10^{-4} \mathrm{M}\right.$ ) were used as probes to examine the possibility of an alteration in the hexose transport system between Days 6 and 7 p.c. The rationale for this approach was that if the control and drug-treated

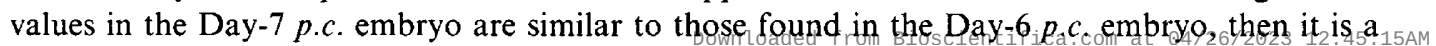


remote possibility that any change occurs in the hexose transport mechanism during this timeframe. Our results indicate that the control value of 3-0MG uptake, and the phloretin/phlorizin $\left(10^{-4} \mathrm{M}\right.$ ) sensitivity in the Day-7 p.c. embryo (control $=11 \cdot 0 \pm 0 \cdot 7 \mathrm{nmol} \cdot \mathrm{cm}^{-2}, n=4$; phlorizin, $10 \cdot 1 \pm 1 \cdot 0 \mathrm{nmol} \cdot \mathrm{cm}^{-2}, n=7$; phloretin, $\left.1.20 \pm 0.15 \mathrm{nmol} \cdot \mathrm{cm}^{-2}, n=6\right)$ were similar to those in the Day 6 p.c. embryo. In addition, insulin $\left(10^{-7} \mathrm{M}\right)$ had no effect at this developmental age (not shown).

\section{Discussion}

Our results indicate that the Day- 6 and -7 p.c. rabbit embryo has a glucose transport system that, at the apical and basolateral membrane, operates independently of external $\mathrm{Na}^{+}$. The apical $\mathrm{Na}^{+}$. independent transport system in the rabbit blastocyst is similar to the system found in the mouse embryo (Dabich \& Acey, 1982; Gardner \& Leese, 1988). However, because of the small size of the mouse blastocyst, which precludes transtrophectodermal flux studies, a basolateral $\mathrm{Na}^{+}$. independent glucose transporter was not discovered. To our knowledge, this is the first report which definitively describes a transtrophectodermal hexose transport system.

The $\mathrm{Na}^{+}$-independence of this apical transport system is in contrast to that normally found in epithelia where the apical system is $\mathrm{Na}^{+}$-dependent and the basolateral membrane contains a $\mathrm{Na}^{+}$. independent hexose transport protein. The hexose transport protein in the apical membrane of the trophectoderm appears to resemble most other $\mathrm{Na}^{+}$-independent glucose transporters in that it has a high specificity for 2-deoxy-D-glucose, and a very low affinity (if any) for 4 - $\alpha$-methyl-glucoside.

Insulin effects on glucose transport have been widely studied in adipose tissues. In rat adipose cells for instance, this hormone causes an increase in the number of glucose transport proteins which are apparently recruited from intracellular pools (Kahn \& Cushman, 1986). The half-time of this response is $3-4 \mathrm{~min}$ and maximum response is noted at $10 \mathrm{~min}$. Our data reveal no significant change in the 3-0MG flux with the application of $10^{-7} \mathrm{M}$-insulin for $10 \mathrm{~min}$. We also found no effect at higher doses of insulin $\left(10^{-5} \mathrm{M}\right)$, or after a $20 \mathrm{~min}$ preincubation period (data not shown). This negative result could result from a number of different factors. It may be that there are no insulin receptors on the rabbit embryo, in contrast with the mouse blastocyst (Rosenblum et al., 1986), or perhaps the mechanism whereby insulin increases the number of hexose transporters does not exist.

We speculate that the glucose transporter in the rabbit embryo resembles the erythrocyte/braintype transporter for the following reasons. The lack of an insulin stimulation and also a cAMP effect on glucose transport, both of which are seen in adipocytes (Karnieli et al., 1981; Joost et al., 1986), makes it improbable that the insulin-responsive protein is present in the embryo. As an additional argument against the presence of an insulin-responsive transporter, immunogold labelling reveals no large intracellular pools of transport protein as was previously seen in unstimulated 3T3-Ll adipocytes (Blok et al., 1988). The glucose transport protein found in the liver is also not a probable candidate because the antibody raised against the $C$-terminus portion does not cross-react with this peptide (Haspel et al., 1988). Thus, the brain-type glucose transport protein is most probably the hexose carrier in the rabbit blastocyst. The mouse embryo may also have a similar system since it also does not respond to insulin (Gardner \& Leese, 1988).

The density of colloidal gold particles at the apical membrane is similar to that found in the adipocyte (Blok et al., 1988). The higher density of colloidal gold particles at the basolateral membrane suggests that the apical membrane, because it has less transport protein, is most likely the rate limiting step in transtrophectodermal hexose transport. However, if the kinetics of hexose transport across the basolateral membrane are very different from those of the apical system, the apical membrane may, in fact, not be rate limiting.

If the basolateral membrane is not the rate-limiting step for transport of glucose across the trophectodermal cell, then glucose, once it enters the cell, will quickly exit across the basolateral membrane. Glucose then will not be available for metabolism because of the brief time period spent in the trophectodermal cell. Rapid exit of glucose does appear to occur as preliminary experiments 
indicate that the glucose flux into the blastocoele displays a half-time similar to the half-time of the 3-0MG flux (D. H. Robinson \& D. J. Benos, unpublished).

Previous studies have shown that PGE-2 and PGF-2 $\alpha$ suppress $\mathrm{CO}_{2}$ production in mouse embryos (Khurana \& Wales, 1987b). To determine whether these hormones have any effect on hexose transport in the rabbit embryo, we examined the effect of exposing the embryos for short periods to PGE-2 or PGF-2 $\alpha$. Neither prostaglandin tested has an effect on 3-0MG transport. This indicates that these prostaglandins may cause their effect on $\mathrm{CO}_{2}$ production at a step other than cellular uptake.

Cyclic AMP (cAMP) is known to decrease the $\mathrm{V}_{\max }$ and/or the $K_{\mathrm{m}}$ for hexose transport in adipose cells (Joost et al., 1986). The negative result found in the rabbit embryo with CPT cAMP, along with the finding that the forskolin effect is most probably the result of a direct interaction with the hexose transport protein (see below), indicate that the glucose transport system in the rabbit blastocyst is not modulated by any hormones that result in the activation of adenylate cyclase.

Forskolin is known to inhibit glucose transport through the erythrocyte transporter (Sargent \& $\mathrm{Kim}, 1985$ ), and this inhibition is most probably a result of forskolin binding directly to the transport protein (Lavis et al., 1987). The rabbit blastocyst transport system is similar in this sensitivity because both forskolin and dideoxyforskolin (which has no adenylate cyclase-stimulating effect) inhibit 3-0MG flux nearly as well as phloretin, a compound which competitively blocks the transport protein.

The lack of a progesterone effect on the uptake of 3-0MG correlates well with the finding that this hormone has no effect on energy metabolism in the mouse embryo (Khurana \& Wales, 1987a). The effect of progesterone found by Perinchief (1980) is most probably a result of the supramaximal concentration of progesterone used.

The flux rate of $3-0 \mathrm{MG}$ found in the embryo is in agreement with that found in unstimulated adipose tissue. In isolated rat adipose cells, an uptake of about $0.2 \mathrm{fmol} \cdot \mathrm{cell}^{-1} \cdot \mathrm{min}^{-1}$ was found in the presence of $0.1 \mathrm{mM}-3-0 \mathrm{MG}$ (Karnieli et al., 1981). At this 3-0MG concentration, we found a rate of uptake of $0.14 \mathrm{nmol} \cdot \mathrm{cm}^{-2} \cdot \mathrm{min}^{-1}$. A previous study found that the surface area of a trophectoderm cell is $3 \cdot 1 \times 10^{-6} \mathrm{~cm}^{2} \cdot \mathrm{cell}^{-1}$ (Daniel, 1964). The 3-0MG uptake, calculated on a cellular basis in the trophectoderm cell, is then about $0.4 \mathrm{fmol}^{-}$cell ${ }^{-1} \cdot \mathrm{min}^{-1}$. Evidently, this flux, which corresponds to the unstimulated flux in an adipose cell, is sufficient to allow equilibration of hexose between the uterine lumen and the blastocoele fluid.

The function of this system, because it is not affected by hormones, is most probably to allow free passage of hexoses in a constitutive manner across the trophectoderm. Early studies have noted that, in blastocysts, glycolysis predominates over the hexose monophosphate shunt pathway whereas the opposite is true in the morula (Fridhandler, 1961). Perhaps it is necessary for the glucose level in the blastocoele to approach that found in the uterus in order to provide energy substrate for the ICM. In fact, measurements indicate that the glucose concentration within the preimplantation rabbit embryo blastocoele is equal to that in the uterine fluid, namely about 0.4-1 mu (Lutwak-Mann, 1954, 1962).

We conclude that the rabbit blastocyst has a $\mathrm{Na}^{+}$-independent glucose transport mechanism located on the apical and basolateral membranes of the trophectoderm. Apparently, this system is constitutively regulated in that the hormones tested have no effect on the transtrophectodermal transport of 3-0-methyl glucose.

Animais used in this study were maintained in accordance with the guidelines of the Animal Use Subcommittee at the University of Alabama at Birmingham and those prepared by the Committee on Care and Use of Laboratory Animals of the Institute of Laboratory Animal Resources, National Research Council [DHEW publication No. (NIH) 85-23, revised 1985]. The University of Alabama at Birmingham has an animal welfare assurance on file with The Office for Protection

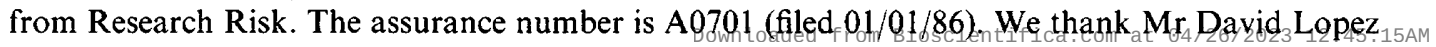


for technical assistance; Ms Cathy Guy for excellent secretarial service; Dr G. E. Lienhard for helpful advise and the antibody to the glucose transport protein; and Roussel UCLAF, Romainville, France, for mifepristone.

The work was supported by NIH grants HD21302 and HD07069.

\section{References}

Benos, D.J. (1981) Developmental changes in epithelial transport characteristics of preimplantation rabbit blastocysts. J. Physiol., Lond. 316, 191-202.

Biggers, J.D., Bell, J.E. \& Benos, D.J. (1988) Mammalian blastocyst: transport functions in a developing epithelium. Am. J. Physiol. 255, C419-432.

Blok, J., Gibbs, E.M., Lienhard, G.E., Slot, J.W. \& Genuze, H.J. (1988) Insulin-induced translocation of glucose transporters from post-golgi compartments to the plasma membrane of $3 \mathrm{~T} 3-\mathrm{Ll}$ adipocytes. $J$. Cell Biol. 106, 69-76.

Dabich, D. \& Acey, R.A. (1982) Transport of glucosamine (aldohexoses) by preimplantation mouse blastocysts. Biochim. Biophys. Acta 684, 146-148.

Daniel, J.C. (1964) Early growth of rabbit trophoblast. Am. Natur. 98, 85-98.

Esposito, G. (1984) Intestinal permeability of watersoluble nonelectrolytes: Sugars, amino acids, peptides. In Pharmacology of Intestinal Permeability, pp. 567-611. Ed. T. Z. Czaky. Springer-Verlag, New York.

Fridhandler, L. (1961) Pathways of glucose metabolism in fertilized rabbit ova at various pre-implantation stages. Expl Cell Res. 22, 303-316.

Gardner, D.K. \& Leese, H.J. (1988) The role of glucose and pyruvate transport in regulating nutrient utilization by preimplantation mouse embryos. Development 104, 423-429.

Gliemann, J. \& Rees, W.D. (1983) The insulin sensitive hexose transport system in adipocytes. Curr. Top. Membr. Transp. 18, 339-379.

Haspel, H.C., Rosenfeld, M.G. \& Rosen, O.M. (1988) Characterization of antisera to a synthetic carboxylterminal peptide of the glucose transporter protein. $J$. biol. Chem. 263, 398-403.

Hastings, R.A. \& Enders, A.C. (1975) Junctional complexes in the preimplantation rabbit embryo. Anat. Rec. 181, 17-34.

Joost, H.C., Weber, T.M., Cushman, S.W. \& Simpson, I.A. (1986 Insulin-stimulated glucose transport in rat adipose cells. Modulation of transporter intrinsic activity by isoproterenol and adenosine. J. biol. Chem. 261, 10033-10036.

Kahn, B.B. \& Cushman, S.W. (1986) Cell biology of insulin's stimulatory action on glucose transport and its perturbation in altered metabolic states. Ann. N.Y. Acad. Sci. 288, 356-369.

Karnieli, E., Zarnowski, M.J., Hissin, P.J., Simpson, I.A., Salans, L.B. \& Cushman, S.W. (1981) Insulinstimulated translocation of glucose transport systems in the isolated rate adipose cell. J. biol. Chem. 256, 4722-4777.

Khurana, N.K. \& Wales, R.G. (1987a) Effects of oestradiol and progesterone on the metabolism of
[U- $\left.{ }^{14} \mathrm{C}\right] \mathrm{glucose}$ by mouse morulae and early blastocysts in vitro. J. Reprod. Fert. 79, 267-273.

Khurana, N.K. \& Wales, R.G. (1987b) Effects of prostaglandins E-2 and F-2 $\alpha$ on the metabolism of [U- ${ }^{14} \mathrm{C}$ ]glucose by mouse morulae-early blastocysts in vitro. J. Reprod. Fert. 79, 275-280.

Kinne, R., Murer, H., Kinne-Saffran, E., Thees, M. \& Sachs, G. (1975) Sugar transport by renal plasma membrane vesicles. J. Memb. Biol. 21, 375-395.

Laemmli, U.K. (1970) Cleavage of structural proteins during the assembly of the head of bacteriophage T4. Nature, Lond. 227, 680-685.

Lavis, V.R., Lee, D.P. \& Shenolikar, S. (1987) Evidence that forskolin binds to the glucose transporter of human erythrocytes. J. biol. Chem. 262, 14571-14575.

Lienhard, G.E., Crabb, J.H. \& Ransome, K.J. (1984) Endoglycosidase $\mathbf{F}$ cleaves the oligosaccharides from the glucose transporter of the human erythrocyte. Biochim. Biophys. Acta 769, 404-410.

Lucas, V.A. \& Zigler, J.S., Jr (1988) Identification of the monkey lens glucose transporter by photoaffinity labeling with cytochalasin B. Invest. Opthalmol. Vis. Sci. 29, 630-635.

Lutwak-Mann, C. (1954) Some properties of the rabbit blastocyst. J. Embryol. exp. Morph. 2, 1-13.

Lutwak-Mann, C. (1962) Glucose, lactic acid and bicarbonate in rabbit blastocyst fluid. Nature, Lond. 193, 653-654.

Matthaei, S., Olefsky, J.M. \& Horuk, R. (1987) Biochemical characterization and subcellular distribution of the glucose transporter from rat brain microvesicles. Biochim. Biophys. Acta 905, 417-425.

Nielsen, L.L., Benos, D.J. \& Biggers, J.D. (1987) Mineralocorticoid concentrations in unstressed female rabbits and embryonic sodium transport. $J$. Reprod. Fert. 81, 553-562.

Perinchief, P.N. (1980) Monosaccharide transport in the preimplanted rabbit blastocyst. Fedn Proc. Fedn Am. Socs exp. Biol. 39, 954, abstr.

Robinson, D.H., Kirk, K.L. \& Benos, D.J. (1989) Macromolecular transport in rabbit blastocysts: evidence for a specific uteroglobin transport system. Molec. cell. Endocrinol. 63, 227-237.

Rosenblum, I.Y., Mattson, B.A. \& Heyner, S. (1986) Stage-specific insulin binding in mouse preimplantation embryos. Devl Biol. 116, 261-263.

Sargent, S. \& Kim, H.D. (1985) Inhibition of 3-0-methyl glucose transport in human erythrocytes by forskolin. J. biol. Chem. 260, 14677-14682.

Ullrich, K.J. (1979) Sugar, amino acid and $\mathrm{Na}^{+}$cotransport in the proximal tubule. Ann. Rev. Physiol. 41, 181-195.

Received 3 April 1989 